\title{
Morphometric and genetic differentiation among populations of Eupemphix nattereri (Amphibia, Anura, Leiuperidae) from central Brazil
}

\author{
Daniela de M. e Silva ${ }^{1,2}$, Aparecido D. da Cruz ${ }^{1}$, Rogério P. Bastos ${ }^{3}$, Mariana P. de C. Telles ${ }^{3}$ \\ \& José Alexandre F. Diniz-Filho 2,3
}

\author{
1. Núcleo de Pesquisas Replicon, Departamento de Biologia, Universidade Católica de Goiás, Avenida Universitária, 1440, 74605-010 \\ Goiânia, Goiás, Brazil. (danielamelo@ucg.br) \\ 2. Programa de Pós-Graduação em Biologia Animal, Universidade de Brasília, Brasília-DF, Brazil. \\ 3. Departamento de Biologia Geral, Instituto de Ciências Biológicas, Universidade Federal de Goiás, Goiânia, Goiás, Brazil.
}

\begin{abstract}
To assess genetic structure and phenotypic diversity of Eupemphix nattereri Steindachner, 1863, morphometric and molecular analyses were carried out for nine populations from the State of Goiás. A total of 11 morphometric traits were evaluated and genetic information was estimated using RAPD markers. Genetic and phenotypic distances were determined as a function of geographical origin. Correlation among genetic, morphometric, micro, and macroenviromental were analyzed by the Mantel test. Genetic data indicated high levels of genetic diversity $\left(\Phi_{\mathrm{st}}=0.3\right)$ among the nine populations. Mantel tests did not reveal a significant positive correlation between genetic and geographical distances, indicating that locally geographical populations were not genetically similar, even in distances smaller than $50 \mathrm{~km}$. Discriminant analysis on 11 morphometric measurements showed a high divergence among the nine populations. However, a marginally significant correlation $(\mathrm{P}=0.08)$ between genetic and morphometric distances was found. The observed correlation was not causal in terms of the relationship between phenotype and genotype, but indicated common spatial structures. Thus, our results suggest that isolation-by-distance processes may explain population divergence in Eupemphix nattereri.
\end{abstract}

KEYWORDS. Eupemphix nattereri, morphology, RAPD markers, gene flow, population structure.

RESUMO. Diferenciação genética e morfométrica em populações de Eupemphix nattereri (Amphibia, Anura, Leiuperidae) do Brasil Central. Visando conhecer a estrutura genética e a diversidade fenotípica da espécie Eupemphix nattereri Steindachner, 1863 , análises morfométricas e moleculares foram realizadas em nove populações do Estado de Goiás. Onze caracteres morfométricos foram avaliados e a diversidade genética foi estimada com o uso de marcadores RAPD. As matrizes de distâncias genéticas e fenotípicas foram correlacionadas com as distâncias geográficas e dados macro e microambientais, utilizando o teste de Mantel. Em relação aos caracteres genéticos, foram encontrados altos níveis de diversidade $\left(\Phi_{\mathrm{st}}=0,3\right)$ entre as nove populações. Não houve, entretanto, uma correlação positiva significativa entre as distâncias genéticas e geográficas, indicando que populações geograficamente próximas não seriam geneticamente similares, mesmo estando situadas entre distâncias menores do que $50 \mathrm{~km}$. Uma análise discriminante dos onze caracteres morfométricos evidenciou também uma elevada divergência entre as nove populações. Entretanto, foi encontrada uma correlação quase significativa $(\mathrm{P}=0,008)$ entre as distâncias genéticas e morfométricas. A correlação observada não foi casual entre fenótipo e genótipo, mas indicou estruturas espaciais comuns. Desta forma, nossos resultados sugerem que processos de isolamento por distância poderiam explicar a divergência populacional na espécie Eupemphix nattereri.

PALAVRAS-CHAVE. Eupemphix nattereri, morfologia, marcadores RAPD, fluxo gênico, estrutura populacional.

At present there are approximately 6,300 species of anuran amphibians over the world (IUCN, 2004), and the largest diversity is found in the Neotropics (DuelLman, 1988). Brazil represents one of the most diverse countries, with 747 species (SBH, 2005). In State of Goiás, more than 70 anuran species are known to occur, corresponding to $9.4 \%$ of Brazil's anuran diversity. However, the anuran fauna remains largely unknown in the central areas of Brazil (BRANDÃo \& ARAúJO, 1998).

Despite the high levels of species diversity, little is known about the population structure of amphibians in South America, due to the scarcity of data referring to the dynamics of the group (MYers et al., 2000; Young et al., 2001). Many studies on population genetic structure of amphibians sustain the idea that among vertebrates, amphibians exhibit relatively low vagility and are highly philopatric (Blaustein et al., 1994; SePPã \& LaURILA, 1999; SHAFFER et al., 2000; LAMPERT et al., 2003), allowing the accumulation of genetic and morphological differences among populations (BLOUIN \& BROWN, 2000; CAMP et al., 2000; MÉNDEZ et al., 2004). Consequently, amphibians have recently become a focus in studies trying to understand ecological and evolutionary processes (Zeisset \& BeEbee, 2003; Eterovick et al., 2005; FunK et al., 2005).

The family Leiuperidae comprises 7 genera, and 48 species, occurring all over the Neotropical region and including species that have terrestrial, fossorials, arboreal, and aquatic habits (Frost et al., 2006).

The genus Eupemphix (Leiuperidae) was described by Steindachner (1863) to include the species Eupemphix nattereri, whose type locality is Cuiabá, Mato Grosso, Brazil (NAScimento et al., 2005). Eupemphix nattereri is a frog largely distributed in South America, ranging from the east of Paraguay to central and southeast Brazil (CEI, 1980; Frost, 2004). At the beginning of the rainy season, males and females are found reproducing in permanent and temporary ponds in open areas 
(BRASILEIRO et al., 2005). The breeding season can extend for many months, characterizing the reproductive pattern as explosive (WELLS, 1977).

Analyses of intraspecific geographical variability in morphology have often revealed extensive variation in body size among amphibians (BABIK \& RAFINSKI, 2000; Castellano et al., 2000; Schäuble, 2004). Body size is a fundamental morphological trait, important in a physiological, ecological, and behavioral context of a species (SchäUble, 2004). However, causes and maintenance of geographical variation in morphology are likely to be complex and not always well understood (Malhotra \& ThORPE, 1997).

Studies based on molecular markers, such as RAPD (Random Amplified Polymorphic DNA) have contributed in a complementary manner to the understanding of amphibian population genetics all over the world (RAFINSKI \& BABIK, 2000; TRAKIMAS et al., 2003; ZEISSET \& BeEBEe, 2003). RAPD are based on randomic amplifications of DNA fragments by small primer sequences of approximately 8 to 10 base pairs (RABOUAM et al., 1999). Dominant markers such as RAPD can be easily developed, even for species without prior genetic information at low costs (Mueller \& WolfenBARGER, 1999). Consequently, RAPD markers represent molecular tools that help answer questions about variations among individuals and populations (VON EGGELING \& Spielvogel, 1995; Cushwa \& Medrano, 1996; Hassanien et al., 2004).

The current paper reports on the association among morphometric, genetic, macroenvironmental, and microenvironmental data of nine populations of Eupemphix nattereri, from the State of Goiás. Our hypothesis is that it is possible to infer the population structure of Eupemphix nattereri by investigating the levels of similarity and genetic diversity between and among populations of this anuran. Thus, it was determined the extent of genetic differentiation of Eupemhix nattereri in Central Brazil using RAPD markers and, it was also evaluated the potential correlations among morphological variation, abiotic factors, and genetic differentiation.

\section{MATERIALS AND METHODS}

Study Area. All nine study areas were located in State of Goiás, central Brazil, between parallels $14^{\circ} \mathrm{N}$ and $19^{\circ} \mathrm{S}$ and the meridians $52.5^{\circ} \mathrm{W}$ and $40^{\circ} \mathrm{E}$, occupying an area of $281,250 \mathrm{Km}^{2}$. The vegetation of these areas is composed by different physiognomies of the Cerrado biome, forming savanna-like vegetation in the welldrained interfluves, and gallery forests along streams and rivers (RATTER et al., 1998).

A total of 132 specimens of E. nattereri were collected at the nine municipalities (Fig.1), during the rainy season of 2002-2004, between October and March. Sampling localities, sample sizes, coordinates, micro environmental characteristics of each municipality are listed in Table I. Voucher individuals were deposited in the Zoological Collection of the Universidade Federal de Goiás (ZUFG).
Morphometric analysis. Eleven external body measurements were taken from each of the 132 adult specimens of $E$. nattereri. All the measurements are expressed in millimeters. Measured specimens were fixed in $10 \%$ formalin and maintained in $70 \%$ ethyl alcohol. For measurements we used an ocular micrometer in a stereomicroscope and calipers to the nearest $0.05 \mathrm{~mm}$. Raw morphometric data were log-transformed to perform a parametric statistical analysis. The descriptions of each measurement are listed in Table II.

Molecular data. Genomic DNA was purified from $20 \mathrm{mg}$ of frozen liver with DNA purification Kit, according to manufacture's procedures. Amplification reactions were performed in a final solution of $20 \mu \mathrm{l}$ with $2.5 \mathrm{ng}$ of genomic DNA, $10 \mathrm{X}$ reaction buffer, $2 \mathrm{mM}$ of $\mathrm{MgCl}_{2}, 0.26 \mathrm{mM}$ of each dNTP, $10 \mathrm{ng}$ of a single primer (Operon Technologies), $0.5 \mathrm{U}$ of Taq DNA-polymerase and double distiled $\mathrm{H}_{2} \mathrm{O}$. The cycling amplification parameters were: initial denaturation at $96^{\circ} \mathrm{C}$ for $3 \mathrm{~min}$, followed by 40 cycles of denaturation for $1 \mathrm{~min}$ at $92^{\circ} \mathrm{C}$, annealing for $1 \mathrm{~min}$ at $35^{\circ} \mathrm{C}$ and elongation for $1 \mathrm{~min}$ at $72^{\circ} \mathrm{C}$. Ten microliters of each reaction product were loaded in a horizontal $1.5 \%$ agarose gel and electrophoresed at $5 \mathrm{~V} / \mathrm{cm}$. The images obtained by each gel were captured using a video-documentation system and analyzed with Image Master 1D software (Total Lab, Amersham Pharmacia Biotech, USA).

A total of 40 primers were tested to select those with the best amplification pattern. The presence of a determined locus was confirmed by the software Master 1 D (Total Lab, Amersham Pharmacia Biotech, USA) by verifying the peaks of the bands during gel analyses. Loci with peaks smaller than 20 pixels, after two repetitions, were excluded from the analyses (Fig. 2).

After this initial evaluation, eigth primers (Tab. III) were used in the analysis of DNA polymorphism between and among populations. The eigth RAPD primers produced a total of 82 distinct, reproducible bands that

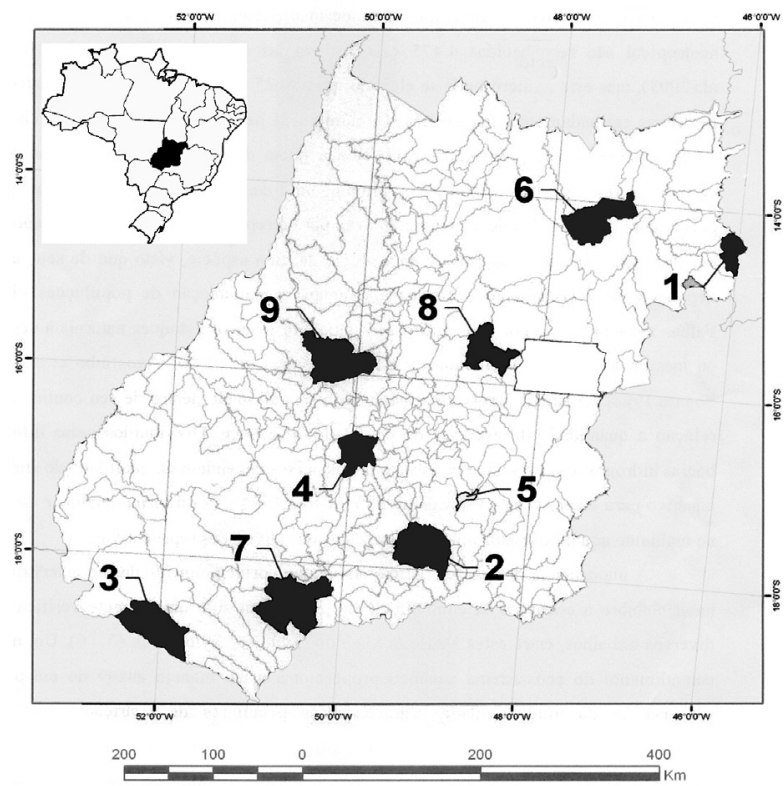

Fig. 1. Map of the State of Goiás, showing the nine sample sites of Eupemphix nattereri Steindachner, 1863 (1, Mambaí; 2, Morrinhos; 3, Aporé; 4, Palmeiras de Goiás; 5, Cristianópolis; 6, Alto Paraíso; 7, Quirinópolis; 8, Cocalzinho de Goiás; 9, Goiás). 
Table I. Geographical and environmental data for the sampling sites of Eupemphix nattereri Steindachner, 1863 populations in Central Brazil (1, Mambaí; 2, Morrinhos; 3, Aporé; 4, Palmeiras de Goiás; 5, Cristianópolis; 6, Alto Paraíso; 7, Quirinópolis; 8, Cocalzinho de Goiás; 9, Goiás).

\begin{tabular}{|c|c|c|c|c|c|c|}
\hline Municipalities & $\mathrm{N}$ & Latitude & Longitude & Air temperature $\left({ }^{\circ} \mathrm{C}\right)$ & Humidity (\%) & Elevation $(\mathrm{m})$ \\
\hline 1 & 20 & $14^{\circ} 29^{\prime} 16^{\prime \prime}$ & $46^{\circ} 06^{\prime} 47^{\prime \prime}$ & 32 & 51 & 709 \\
\hline 2 & 24 & $17^{\circ} 43^{\prime} 54^{\prime \prime}$ & $49^{\circ} 06^{\prime} 03^{\prime \prime}$ & 24 & 80 & 771 \\
\hline 3 & 13 & $18^{\circ} 57^{\prime} 55^{\prime \prime}$ & $51^{\circ} 55^{\prime} 35^{\prime \prime}$ & 25 & 60 & 538 \\
\hline 4 & 10 & $16^{\circ} 48^{\prime} 18^{\prime \prime}$ & $49^{\circ} 55^{\prime} 33^{\prime \prime}$ & 28 & 84 & 596 \\
\hline 5 & 13 & $17^{\circ} 11^{\prime} 96^{\prime \prime}$ & $48^{\circ} 42^{\prime} 14^{\prime \prime}$ & 20 & 70 & 802 \\
\hline 6 & 21 & $14^{\circ} 07^{\prime} 57^{\prime \prime}$ & $47^{\circ} 30^{\prime} 36^{\prime \prime}$ & 25 & 67 & 1186 \\
\hline 7 & 13 & $18^{\circ} 26^{\prime} 54^{\prime \prime}$ & $50^{\circ} 27^{\prime} 06^{\prime \prime}$ & 27 & 63 & 541 \\
\hline 8 & 12 & $15^{\circ} 47^{\prime} 40^{\prime \prime}$ & $48^{\circ} 46^{\prime} 33^{\prime \prime}$ & 25 & 85 & 1152 \\
\hline 9 & 08 & $15^{\circ} 56^{\prime} 04^{\prime \prime}$ & $50^{\circ} 08^{\prime \prime} 25^{\prime \prime}$ & 24 & 73 & 802 \\
\hline
\end{tabular}

Table II. Standardized morphometric measurements carried out on specimens of Eupemphix nattereri from central Brazil.

\begin{tabular}{lll}
\hline Measurement & Abbreviation & \multicolumn{1}{c}{ Description } \\
\hline Snout-vent length & SVL & From tip of snout to posterior margin of vent \\
Femur length & FL & Cloacae to Knee \\
Head Wide & HW & Measured between mean edges of head \\
Anterior interorbital distance & AID & Distance between anterior edges of eyes \\
Eye-nostril distance & END & Distance between anterior edge of eye and posterior edge of nostrils \\
Snout-nostril distance & SND & Distance between anterior egde of snout and posterior edge of nostrils \\
Foot length & F & Tip of longest toe to back of heel \\
Tibia length & TL & Knee to heel \\
Head length & HL & Distance between anterior and posterior edge of head \\
Interorbital distance & OO & Shortest distance between eye sockets \\
Tympanum diameter & TD & Maximum distance between rims of tympanum \\
\hline
\end{tabular}

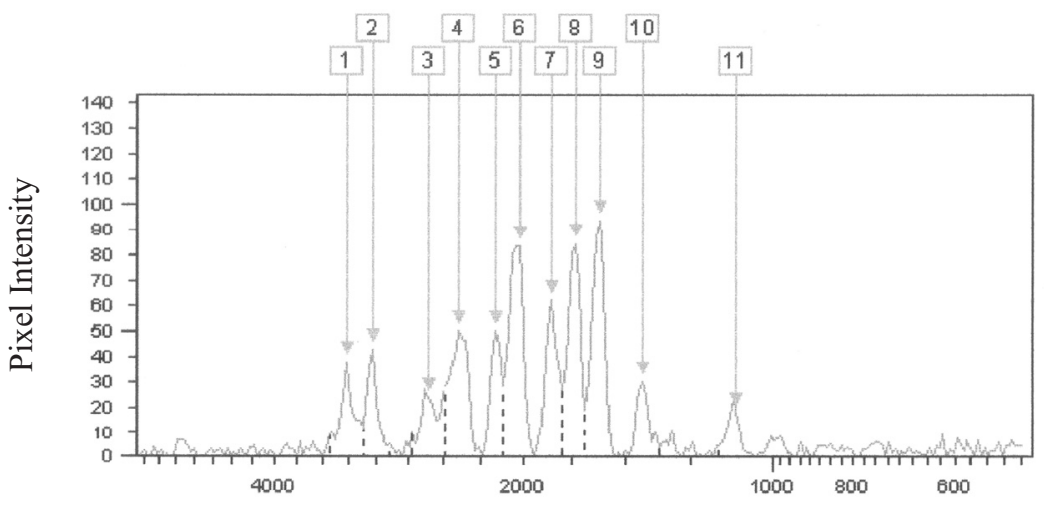

Base Pairs

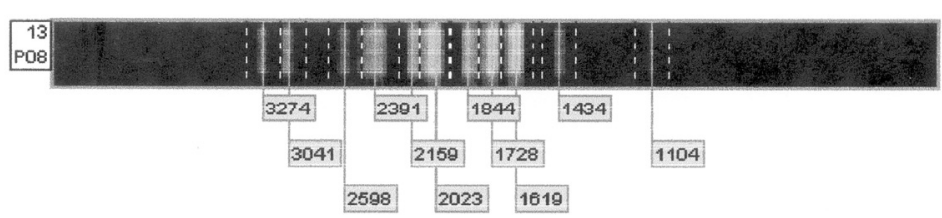

Fig. 2. Results of the RAPD marker analysis for the primer OPA13, obtained from one individual of Eupemphix nattereri Steindachner, 1863 from Palmeiras municipality, central Brazil, using the software Image Master 1D (Amersham Pharmacia Biotech, USA). The amplicons varied from 1.104 to $3.274 \mathrm{bp}$ and band intensity ranged from 25 to 90 pixels for eleven amplified loci. Peak cut off < 20 pixels (1, locus of $3274 \mathrm{bp} ; 2$, locus of $3041 \mathrm{bp} ; 3$, locus of $2598 \mathrm{bp} ; 4$, locus of $2391 \mathrm{bp} ; 5$, locus of $2159 \mathrm{bp} ; 6$, locus of $2023 \mathrm{bp} ; 7$, locus of $1844 \mathrm{bp} ; 8$, locus of $1728 \mathrm{bp} ; 9$, locus of $1619 \mathrm{bp} ; 10$, locus of $1434 \mathrm{bp} ; 11$, locus of $1104 \mathrm{bp}$ ).

comprised the complete data set. A binary matrix was constructed from the gel readings, where the individuals were genotypically characterized for presence (1) and absence (0) of bands.

Statistical analysis. To determine the degree of morphological differentiation between and among populations, and to identify which biometric parameter most contributed for the variation in morphology, analyses of variance (ANOVA) were performed. Components of variance of ANOVA model II permitted the estabilishment of the variation between and among local populations, for each trait. Patterns of morphometric 
discrimination were examined by canonical analysis or multiple discriminant analysis (NeFF \& MARCus, 1980).

The eleven morphometric characteristics were logtransformed, the eigenvalues and eigenvectors were obtained by the product of the variance-covariance matrix between and among populations (NEFF \& MARCUS, 1980). The Mahalanobis distance squared (MDS) obtained by the canonical scores, was used to visualize the pattern of morphometric differentiation among the nine populations. All analyses were performed using the software SYSTAT/ SYSGRAPH (BROWNE \& MELs, 2000).

Analysis of molecular variance (AMOVA) of the genetic matrix was obtained by Euclidean distances between all pairs of haplotypes (ExCOFFIER et al., 1992). AMOVA was performed by partitioning the total variation among and within population, using that Euclidean distances. Total variation was expressed by the $\Phi_{\text {st }}$ coefficient and the significance was tested using 1,000 permutations. All statistical analyses were performed with WINAMOVA software, from L. Excoffier (University of Geneva). Genetic similarity dendograms among the nine populations were constructed by using the $\Phi_{\text {st }}$ coefficients and the UPGMA grouping method (SNEATH \& Sokal, 1973). The significance of the dendogram was tested by a cophenetic correlation with 5,000 permutations, using the software NTSYS 1.5 (RoHLF, 1989).

Mantel test (MANLY, 1997) using NTSYS 1.5 (RoHLF, 1989) was used to determine the significance of correlations using matrices of pairwise distances between populations, with 1,000 randomizations. Microenvironmental variables used in the analyses included: relative air temperature, air humidity, and altitude. Macroenvironmental data were obtained from the Atlas of Biosphere (SET, 2002), using a grid formate of ArcView archive. All cells from the grid contained the coordinates for each municipality.

The following distance matrices were used in these analyses: (a) the morphological matrix of morphometric distances (Mahalanobis distances) among populations; (b) the genetic matrix obtained by AMOVA; (c) the geographical distance matrix; (d) the matrix of Euclidean distances among populations, using standardized macroenviromental data (media $=0$ and variance $=1$ ); and (e) the matrix of microenviromental data.

Table III. Selected primers, primers sequences, and the number of polymorphic loci used in the population study of Eupemphix nattereri Steindachner, 1863 from central Brazil.

\begin{tabular}{lcc}
\hline Primers & Primers sequences $5^{\prime} \rightarrow 3^{\prime}$ & Polymorphic loci \\
\hline OPA13 & CAGCACCCCAC & 14 \\
OPB04 & GGACTGGAGT & 7 \\
OPB06 & TGCTCTGCCC & 7 \\
OPB07 & GGTGACGCAG & 13 \\
OPB10 & CTGCTGGGAC & 10 \\
OPB11 & GTAGACCCGT & 12 \\
OPB18 & CCACAGCAGT & 6 \\
OPC20 & ACTTCGCCAC & 12 \\
Total & & 81 \\
\hline
\end{tabular}

\section{RESULTS}

ANOVA detected differences among populations (Tab. IV) related to the 11 morphometric characteristics. Canonical Variates Analysis confirmed the significant difference among populations $(\lambda$ de Wilks $=0.17 ; \mathrm{P}=0)$. The first canonical variable (VC1) detected differences among the nine populations mainly for SVL, HW and HL. The second canonical variables (CV2) which indicate limb measurements, such as FL, F and TL, exhibited positive correlations, demonstrating morphometric variation among anuran populations (Tab. V). The scores of the two canonical variables for each population are shown in Fig. 3.

The size of the amplicons varied from 100 to 2,000 base pairs. The number of RAPD fragments by primer varied from 6 to 14 (Tab. III). AMOVA indicated a variation of $70 \%$ between populations and $30 \%$ among populations (Tab.VI). The $\Phi_{\mathrm{st}}$ coefficient indicated a significant difference among populations, suggesting low gene flow among individuals and high fidelity to the breeding site. UPGMA showed genetic distances among the nine populations (Fig. 4) and the cophenetic correlation coefficient was $r=0.80$.

Macroenviromental data had mean pluviometric indexes of $91.9(\mathrm{SD}= \pm 6.8)$, annual temperatures of $23^{\circ} \mathrm{C}$ $(\mathrm{SD}= \pm 0.7)$, and relative air humidity of $68.5 \%$

Table IV. Results of Analysis of Variance (ANOVA) for 11 morphometric traits of Eupemphix nattereri Steindachner, 1863 including variance components among populations (V\%) and the levels of significance at $95 \%$ and $99 \%(*, \mathrm{P}<0.05 ; * *, \mathrm{P}<0.01$ $* * *, \mathrm{NS}=$ non significant).

\begin{tabular}{ccc}
\hline Morphometric variables & $\mathrm{F}$ & $\mathrm{V}(\%)$ \\
\hline SVL & $8.7 * *$ & 35.8 \\
HW & $6.8 * *$ & 30.2 \\
FL & $4.1 * *$ & 20.9 \\
F & $5.0 * *$ & 24.1 \\
T L & $3.0 * *$ & 16.3 \\
IO & $2.9 * *$ & 15.7 \\
TD & $3.4 * *$ & 7.9 \\
SND & $4.0 * *$ & 20.4 \\
END & $2.0 *$ & 11.4 \\
HL & $4.7 * *$ & 23.2 \\
AID & $0.9 * * *$ & 5.7 \\
\hline
\end{tabular}

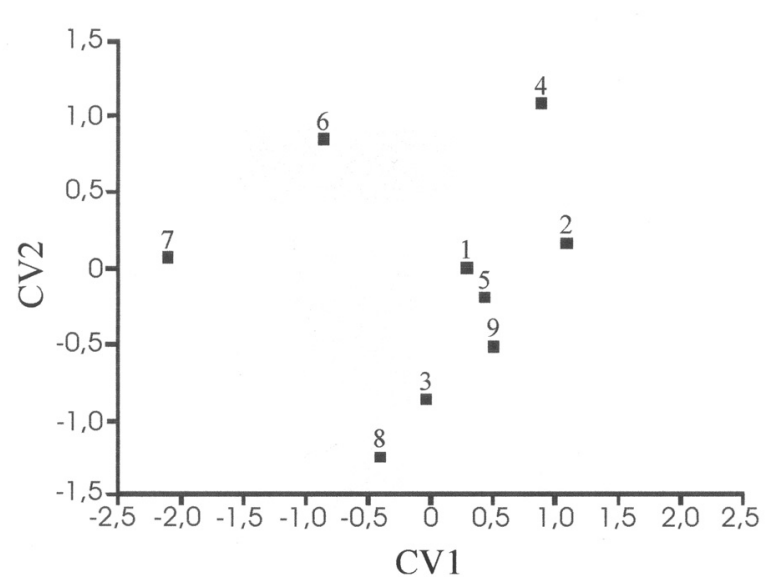

Fig. 3. Results of Canonical Variable Analysis, showing the relative position of each population of Eupemphix nattereri Steindachner, 1863. Numbers 1 to 9 refer to the populations listed on table I. 
( $\mathrm{SD}= \pm 2.0)$. Mean Air temperatures, humidity, and altitude were $25.5^{\circ} \mathrm{C}(\mathrm{SD}= \pm 3.3), 70 \%(\mathrm{SD}= \pm 11)$, and $789 \mathrm{~m}$ $(\mathrm{SD}= \pm 239)$, respectively.

Results of the correlation matrix obtained by Mantel test are summarized in Fig. 5. There was a

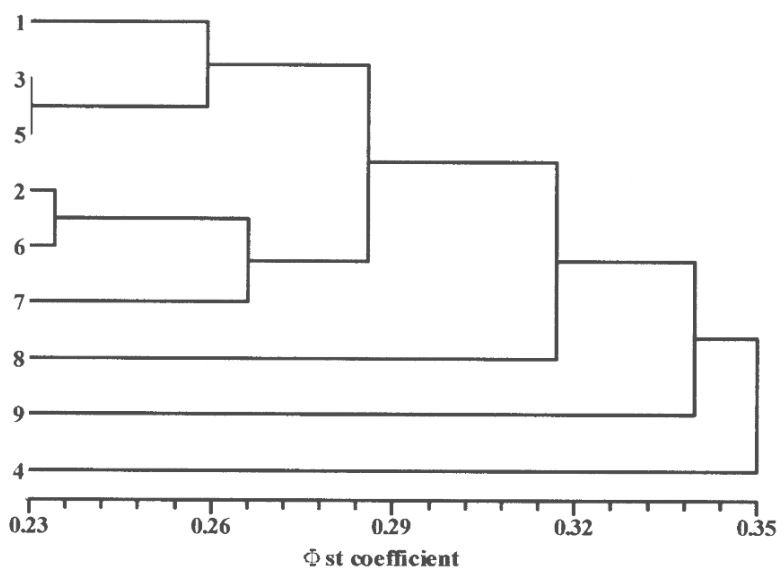

Fig. 4. Dendogram of genetic distance among nine populations of Eupemphix nattereri Steindachner, 1863, defined by UPGMA clustering method, based on genetic divergence $\left(\Phi_{\mathrm{st}}\right)$. significant statistical correlation $(\mathrm{r}=0.75 ; \mathrm{P}=0.001)$ between geographical and macroenvironmental matrixes (pluviometric indexes, mean temperature, and air humidity). A marginally positive correlation ( $\mathrm{P}=0.08)$ was found between morphometric and genetic variation (Fig. 6), which could be explained by evolutionary forces, selecting the genetic make up responsible for morphological traits in E. nattereri. No correlation was observed between morphometric variation and

Table V. Canonical coefficientes of original morphometric traits of Eupemphix nattereri Steindachner, 1863 logarithmized at the first two axes.

\begin{tabular}{lcr}
\hline Variables & CV1 & CV2 \\
\hline SVL & -0.72 & 0.26 \\
HW & -0.63 & -0.05 \\
FL & -0.33 & 0.45 \\
F & -0.26 & 0.47 \\
T L & -0.16 & 0.41 \\
IO & -0.27 & 0.12 \\
TD & -0.40 & -0.09 \\
SND & -0.43 & 0.28 \\
END & -0.32 & -0.05 \\
HL & -0.52 & -0.05 \\
AID & -0.15 & 0.14
\end{tabular}

Table VI. Analysis of Molecular Variance (AMOVA) based on 82 polymorphic RAPD loci for nine populations of Eupemphix nattereri Steindachner, 1863 from Central Brazil (DF, degree of freedom).

\begin{tabular}{lccccccc}
\hline $\begin{array}{l}\text { Source of } \\
\text { variation }\end{array}$ & DF & Sum of squares & Mean Square & Variance & $\begin{array}{c}\text { Total } \\
\text { variance }(\%)\end{array}$ & $\begin{array}{c}\text { P } \\
\text { statistics }\end{array}$ \\
\hline $\begin{array}{l}\text { Population } \\
\text { Individual }\end{array}$ & 8 & 777.1 & 97.1 & 5.8 & $29.9 \%$ & $<0.001$ \\
\hline
\end{tabular}

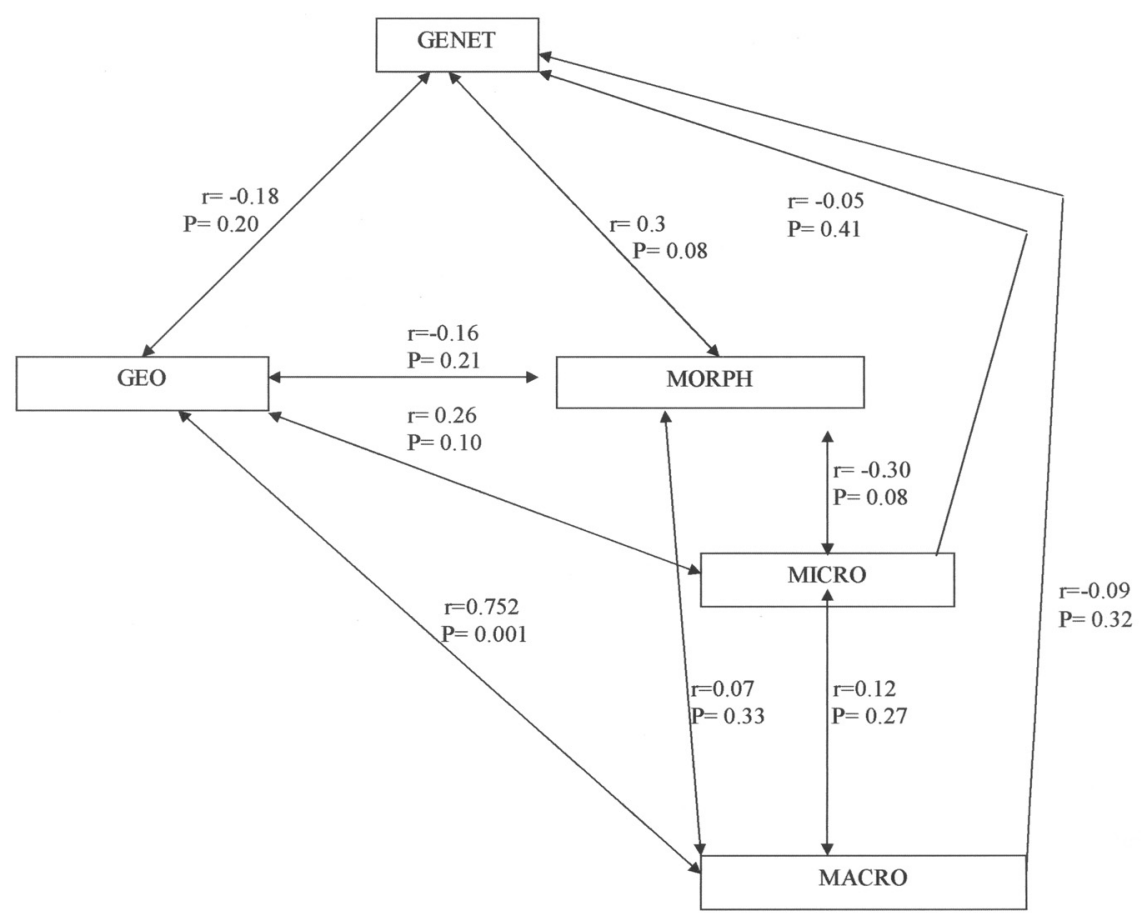

Fig. 5. Resume of Mantel test performed among geographical (GEO), genetic (GENET), morphometrical (MORPH), microenvironmental (MICRO) and macroenvironmental (MACRO) data. 


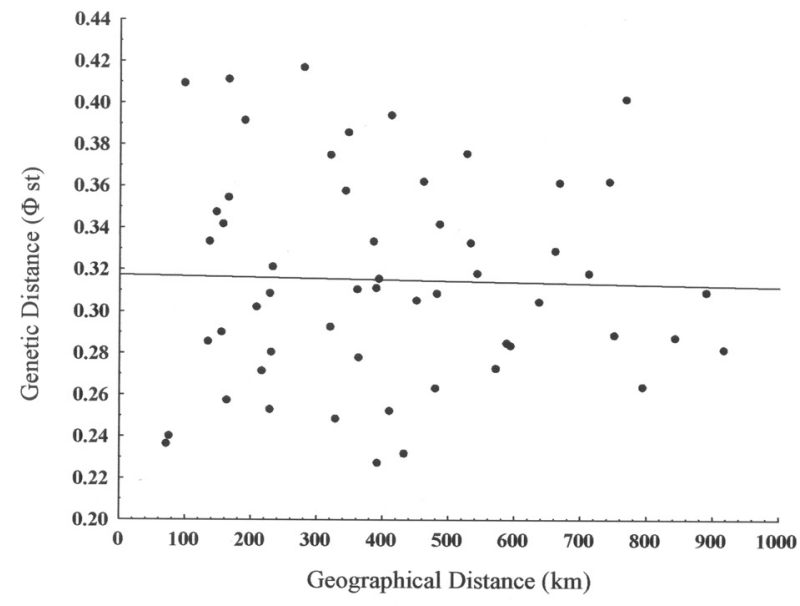

Fig. 6. Graphical representation of Mantel test between geographical and genetic distances for Eupemphix nattereri Steindachner, 1863 population in Central Brazil.

microenviromental data. Although significant correlations were not obtained between morphometric distance and macroenviromental data, all nine populations of $E$. nattereri reported here did not present a spatial pattern with respect to genetic and geographical distances.

\section{DISCUSSION}

Body size and head length were the two variables that mostly contributed for significant differences related to morphometric traits, as observed for other groups (Castellano \& Giacoma, 1998; Castellano et al., 1999; BABIK \& RAFInSKI, 2000; CASTEllano et al., 2000; MÉNDEZ et al., 2004, Rosso et al., 2004). According to our results, the variation in morphological traits did not present a spatial pattern, showing a substantial overlap in overall morhometric variables of the studied populations.

In a study performed with 22 populations of Physalaemus cuvieri Fitzinger, 1826 also from the Cerrado, showed that individuals located in dryer sites in the north of State of Goiás had larger sizes (Juliano \& Bastos, unpublished data). However, the difference in body size along a latitudinal gradient of humidity could happen because animals from wet climates reproduce earlier than populations in dryer climates; thus, size is only a consequence of climate-driven reproductive activity (CASTELLANO et al., 2000). Other component that may influence morphological variation in amphibians is the specific vegetation at each area. Most morphological traits correlates with one another, either body shape or body size varies according to their habitat (Rosso et al., 2004). In our study, all populations of $E$. nattereri were sampled in areas of Cerrado. It is known that this vegetation is a mosaic, and even in the closest areas there is a wide variation in the kind of vegetation throughout Cerrado ecossystems (BRASILEIRO et al., 2005).

In anuran amphibians, adult body sizes depend on many factors including time of metamorphosis, growth rate before and after maturity, age of maturity, and longevity (Rosso et al., 2004). Moreover, genetic and environmental differences can cause diversity in ontogenetic development, resulting in body size variation. Thus, besides ecological factors, genetic, physiological and ontogenetic factors may also explain the wide range of trait variations found in $E$. nattereri. Our data suggest that ecological and genetic factors act in synergism to increase specimen's variation. Because of the complex patterns of morphometric traits, the environmental variables used in this study could not account for the intricate steps beyond the evolutionary mechanisms of Cerrado's anurans. Consequently, the correlation observed between phenotypic and environmental matrixes of distances was only marginal.

It must be consider that other factor in local scales, not analyzed in this study, such as pond temperatures and $\mathrm{pH}$, during the development of tadpoles could influence morphometric traits, as described to Rana arvalis (RÄsÄNEN et al., 2003). The water has a potential effect on morphology and larval development and, therefore, is a relevant factor affecting body size in ectotherms (Atkinson, 1996).

With respect to the genetic differentiation, high level of diversity was found $\left(\Phi_{\mathrm{st}}=0.3\right)$ among the studied populations. There was not a statistically significant correlation between genetic and geographical distances, indicating that sites geographically close were not genetically similar. Many studies of intraspecific genetic variation in anurans have been conducted along extended scales, of many kilometers, and their results show a substantial variation among populations (LAMPERT et al., 2003; Trakimas et al., 2003; Zeisset \& Beebee, 2003; Palo et al., 2004; Telles, 2005). Thus, our data pointed out a strong evidence to support the previous statement even for places situated as close as $50 \mathrm{~km}$.

According to Newman \& SQuiRe (2001), there are explanations, other than just limited gene flow, both genetic and evolutive for local differentiation in neutral markers. At fine spatial and temporal scales, where mutation is less likely to be an important factor, population genetic structure depends on the relative rates of gene flow and dynamics of population size, which determine the rate of genetic drift and turnover of local populations. Even when there is some exchange of individuals among populations, if effective population size is small, fine-scale differentiation may result from high rates of drift and that may be the case for the populations used in this study.

Therefore, a statistical significant correlation, between morphometric and genetic data in the populations of Eupemphix nattereri indicates that the divergence among populations of this species must follow the model of isolation by distance, and even morphometric and genetic variations could be influenced by a spatial structure, although in a fine scale. The results of the current study showed no sufficient evidence to provide no more than a tentative explanation for the spatial structure of $E$. nattereri population in central Brazil. However, as genetic variation is probably neutral and therefore could not be associated to morphometric variation, the trends for a positive correlation could only be explained by isolation by distance.

In conclusion, the results of the current study indicated limited gene flow among the populations of 
Eupemphix nattereri. Several recent studies showed that amphibians avoid open habitats, as fields and roads, moving mostly in forest areas (MADISON \& FARRAND, 1998; Rothermel \& SMelistch, 2002). This peculiar behaviour occurs because of increased risks of desiccation and predation in open areas (SPEAR et al., 2005). As the sample sites were representative of Cerrado biome, characterized by open areas, amphibian behaviour could be responsible for the reduced gene flow, causing simultaneously genetic and morphological differentiation among populations.

Acknowledgments. The authors thank L. D. Guimarães and W. V. Silva for their support during field collections and F. Lobo for the map. We also thank S. Quail for proofreading this manuscript. To IBAMA for the sample license number 017/05. To CNPq (proc. 520804/99-6, 465137/00-8 and 474.189/03-1) and PRONEX (SECTEC-GO proc. 23234156) for their support. To CNPq, for J. A. F. Diniz-Filho, R. P. Bastos and M. P. C. Telles fellowships, and to Pró-Reitoria de Pesquisa e Pós-Graduação from Universidade Católica de Goiás for financial support.

\section{REFERENCES}

Atchley, W. R.; Rutledge, J. J. \& Cowley, D. E. 1982. A multivariate statistical analysis of direct and correlated response to selection in the rat. Evolution 36:677-698.

Atkinson, D. 1996. Ectotherm life-history responses to developmental temperature. In: Johnston, I. A. \& BennetT, A. F. eds. Animals and temperature: phenotypic and evolutionary adaptation. Cambridge, Cambridge University. p. 183-204.

BABIK, W. \& RAFINSKI, J. 2000. Morphometric differentiation of the moor frog (Rana arvalis Nilss.) in Central Europe. Journal of Zoology and Systematic Evolutionary Research 38:239-24.

Blaustein, A. R.; Wake, D. B. \& Sousa, W. P. 1994. Amphibian declines: judging stability, persistence, and susceptibility of populations to local and global extinctons. Conservation Biology 8:60-71.

Blouin, M. S. \& Brown, S. T. 2000. Effects of temperatureinduced variation in anuran larval growth rate on head width and leg length at metamorphosis. Oecologia 125:358-361.

Bos, D. H. \& Sites-JR, J. W. 2001. Phylogeography and conservation genetics of the Columbia spotted frog (Rana luteiventris; Amphibia, Ranidae). Molecular Ecology 10: 1499-1513.

Brandão, R. A. \& AraúJo, A. F. B. 1998. A herpetofauna da Estação Ecológica de Águas Emendadas. In: Marinho-Filho, Rodrigues F. \& Guimarães M. eds. Vertebrados da Estação Ecológica de Águas Emendadas. História Natural e Ecologia em um fragmento de cerrado do Brasil Central. Brasília, SEMATEC/IEMA. p.9-21.

Brasileiro, C. A.; Sawaya, R. J.; Kiefer, M. C. \& Martins, M. 2005. Amphibians of an open cerrado fragment in southeastern Brazil. Biota Neotropica 5(2):1-17. Available at: <http:// www.biotaneotropica.org.br/v5 n $2 / \mathrm{pt} / \mathrm{abstract}$ ? article+ BN0040522005> Access on: 20.02.2006.

Browne, M. \& Mels, G. 2000. SYSTAT 10- Statistics 10 Statistics II. SPSS Inc., Chicago.

BuskiRK, V. \& ARIOLI, M. 2005. Habitat specialization and adaptive phenotypic divergence of anuran populations. Molecular Biology 18:596-608.

Camp, C.; Marshall, J. L. \& Austin, R. M. 2000. The evolution of adult body size in black-bellied salamanders (Desmognathus quadramaculatus complex). Canadian Journal of Zoology 78:1712-1722.

Castellano, S. \& Giacoma, C. 1998. Morphological variation of the green toad, Bufo viridis, in Italy: A Test of Causation. Journal of Herpetology 32(4):540-550.

Castellano, S.; Rosso, A.; Doglio, S. \& Giacoma, C. 1999. Body size and calling variation in the green toad Bufo viridis. Journal of Zoology 248:83-90.
Castellano, S.; Giacoma, C. \& Dujebayeva, T. 2000 Morphometrical and advertisement call geographic variation in polyploid green toads. Biological Journal of the Linnean Society 70:341-360.

CeI, J. M. 1980. Amphibians of Argentina. Italian Journal of Zoology 2:1-690.

Cushwa, W. T. \& Medrano, J. F. 1996. Applications of the random amplified polymorphic DNA (RAPD) assay for genetic analysis of livestock species. Animal Biotechnology 7:11-31.

Duellman, W. E. 1988. Patterns of species diversity in anuran amphibians in the American Tropics. Annals of the Missouri Botanical Garden 75:79-104.

Eterovick, P. C.; Carnaval, A. C. O. Q.; Borges-Nojosa, D. M.; Silvano, D. L. \& Segalla, M. V. 2005. Amphibian Declines in Brazil: An Overview. Biotropica 37:166-179.

Excoffier, L., Smouse, P. E. \& Quattro, J. M. 1992. Analysis of molecular variance inferred from metric distances among DNA haplotypes: application to human mitochondrial DNA restriction data. Genetics 131:479-491.

Frost, D. R. 2004. Amphibian Species of the World: An Online Reference. American Museum of Natural History, USA. Available at: <http://research.amnh.org/herpetology/ amphibia/index.html>. Access on: 31.01.2006.

Frost, D. R.; Grant, T.; Faivovich, J.; Bain, R. H.; HaAs, A.; Haddad, C. F. B.; de Sa, R. O.; Channing, A.;Wilkinson, M.; Donnellan, S. C.; Raxworthy, C. J.; Campbell, J. A.; Blotto, B. L.; Moler, P.; Drewes, R. C.; Nussbaum, R. A.; Lynch, J. D.; Green, D. M. \& WheELer, W. C. 2006. The amphibian tree of life. Bulletin of the American Museum of Natural History 297:1-371. Available at: <http://hdl.handle.net/2246/ 5781>. Access on: 22.07.2007.

Funk, W. C.; Greene, A. E.; Corn, P. S. \& Allendor, F. W. 2005. High dispersal in a frog species suggests that it is vulnerable to habitat fragmentation. Biological Letters 1-4. Available at: 〈http://www.royalsoc.ac.uk〉. Access on: 12.12.2005.

Hassanien, H. A.; Elnady, M.; Obeida, A. \& Itriby, H. 2004. Genetic diversity of Nile tilapia populations revealed by randomly amplified polymorphic DNA (RAPD). Aquaculture Research 35:587-593.

IUCN. 2004. Conservation International and Nature Serve. Global Amphibian Assessment. Available at: <http:// www.globalamphibians.org>. Access on: 31.01.2006.

Juliano, R. F. 2003. Variação geográfica, morfométrica e acústica em Physalaemus cuvieri FITZINGER, 1826 (Amphibia:Anura:Leptodactylidae) no Cerrado do Brasil Central. Dissertação de Mestrado, Universidade Federal de Goiás, Goiânia.

Lampert, K. P.; Rand, A. S.; Mueller, U. G. \& Ryan, M. J. 2003. Fine-scale genetic pattern and evidence for sex-biased dispersal in the túngara-frog, Physalaemus pustulosus. Molecular Ecology 12:3325-3334.

Lenzi-Mattos, R., Antoniazzi, M. M.; Haddad, C. F. B.; Tambourgi, D. V.; Rodrigues, M. T. \& Jared, C. 2005. The inguinal macroglands of the frog Physalaemus nattereri (Leptodactylidae): structure, toxic secretion and relationship with deimatic behaviour. Journal of Zoological 266:385-394.

Lynch, M \& Millingan, B. G. 1994. Analysis of population genetic structure with RAPD markers. Molecular Ecology 3:91-99.

Madison, D. M. \& FARRAND, L. 1998. Habitat use during breeding and emigration in radio implanted tiger salamanders, Ambystoma tigrinum. Copeia 1998:402-410.

Manly, B. F. J. 1997. Randomization, Bootstrap and Monte Carlo methods in biology. London, Chapman \& Hall. 428p.

Méndez, M. A.; Soto, E. R.; Correa, C.; Veloso, A.; Vergara, E.; Sallaberry, M. \& IturRa, P. 2004. Morphological and genetic differentiation among Chilean populations of Bufo spinulosus (Anura: Bufonidae). Revista Chilena de História Natural 77:559-567.

Monteiro, L. R. \& Reis, S. F. 1999. Princípios de Morfometria Geométrica. Ribeirão Preto, Holos. 188p.

Mueller, U. G. \& Wolfenbarger, L. L. 1999. AFLP genotyping and fingerprinting. Trends in Ecology \& Evolution 14 389-394. 
Myers, N.; Mittermeier, R. A.; Mittermeier, C. G.; Fonseca, G. A. B. \& Kent, J. 2000. Biodiversity hotspots for conservation priorities. Nature 403:853-858.

Nascimento, L. B.; Caramaschi, U. \& Cruz, C. A. G. 2005. Taxonomic Review of the Species Groups of the Genus Physalaemus Fitzinger, 1826. Arquivos do Museu Nacional 63:297-320.

NefF, N. A. \& Marcus, L. F. 1980. A Survey of Multivariate Methods for Systematics. New York, privately published. $234 \mathrm{p}$.

Newman, R. A. \& Squire, T. 2001. Microsatellite variation and fine-scale population structure in the wood frog (Rana sylvatica). Molecular Ecology 10:1087-1100.

Palo, J. U.; Schmeller, D. S.; Laurila, A.; Primmer, C. R.; Kuzmin, S. L. \& Merila, J. 2004. High degree of population subdivision in a widespread amphibian. Molecular Ecology 13(9):2631-2644.

Rabouam, C.; Comes, A. M.; Bretagnolle V.; Humbert, J-F.; PeriQuets, G. \& Bigot, Y. 1999. Features of DNA fragments obtained by random amplified polymorphic DNA (RAPD) assays. Molecular Ecology 8:493-503.

RAFINSKI, J. \& BABIK, W. 2000. Genetic differentiation among nothern and southern populations of the moor frog Rana arvalis Nilsson in Central Europe. Heredity 84:610-618.

Räsänen, K.; Laurila, A. \& Merilë, J. 2003. Geographic variation in acid tolerance of the moor frog, Rana arvalis in local adaptation. Evolution 57:352-362.

Ratter, J. A.; Ribeiro, J. F. \& Bridgewater, S. 1998. The Brazilian Cerrado vegetation and threats to its biodiversity. Annals of Botany 80:223-230.

Rohlf, F. J. 1989. NTSYSpc: Numerical Taxonomy and Multivariate Analysis System. New York, Exeter. 800p.

Rosso, A.; Castellano, S. \& Giacoma, C. 2004. Ecogeographic analysis of morphological and life-history variation in the Italian frog. Evolutionary Ecology Research 18:303-321.

Rothermel, B. B. \& Semlistsch, R. D. 2002. An experimental investigation of landscape resistance of forest versus old-field habitats to emigrating juvenile amphibians. Conservation Biology 16:1324-1332.

Sazima, I. \& Caramaschi, U. 1986. Descrição de Physalaemus deimaticus, sp. n., e observações sobre comportamento deimático em Physalameus nattereri (Steindachner) - Anura, Leptodactylidae. Revista de Biologia 13:91-101.

SBH. Sociedade Brasileira de Herpetologia. 2005. Lista de espécies de anfíbios do Brasil. Sociedade Brasileira de Herpetologia (SBH). Available at: <http://www.sbherpetologia.org.br/ checklist/anfibios.htm>. Access on: 31.01.2006.
Seppẽ, P. \& Laurilla, A. 1999. Genetic structure of island populations of the anurans Rana temporaria and Bufo bufo. Heredity 82:309-317.

SET, P. 2002. Atlas of Biosphere. Available at:: <http:// www.sage.wisc.edu/atlas/index.php>. Access on: 10.01.2008.

Shaffer, H. B.; Fellers, G. M.; Magee, A. \& Voss, S. R. 2000. The genetics of amphibian declines: population substructure and molecular differentiation in the Yosemite toad, Bufo canourus (Anura, Bufonidae) based on single strand conformation polymorphism analysis (SSCP) and mithocondrial DNA sequence data. Molecular Ecology 9:245-257.

Sneath, P. H. A. \& Sokal, R. R. 1973. Numerical Taxonomy: The Principles and Pratice of Numerical Classification San Francisco, W. H. Freeman. 573p.

Spear, S. F.; Peterson, C. R.; Matoce, M. D. \& Storfer, A. 2005. Landscape genetics of the blotched tiger salamander (Ambystoma tigrinum melanostictum). Molecular Ecology 14:2553-2564.

Trakimas, G.; Matsui, M.; Nishikawa, K. \& Kasugai, K. 2003. Allozyme variation among Populations of Rana pirica (Amphibia: Anura). Journal of Zoology Systematic Evolutionary Research 41:73-79.

Telles, M. P. C.; Diniz, J. A. F.; Bastos, R.P.; Soares, T.N.; Guimarães, L. D. \& Lima, L. P. 2007. Landscape genetics of Physalaemus cuvieri in Brazilian Cerrado: Correspondence between population structure and patterns of human occupation and habitat loss. Biological Conservation 139:37-46.

Von Eggeling, F. V. \& Spielvogel, H. 1995. Applications of random PCR. Celular and Molecular Biology 41:653-670.

Wells, K. D. 1977. The social behaviour of anuran amphibians. Animal Behaviour 25:666-693.

WilbuR, H. M. 1997. Experimental ecology of food webs: complex systems in temporary ponds. Ecology 78:2279-2302.

WILCZYNSKY, W. \& RYAN, M. J. 1999. Geographic variation in animal communication systems. In: Foster, A. \& Endler, J. eds. Geographic Variation in Behavior-Perspectives on Evolutionary Mechanisms. Oxford \& New York, Oxford University. p.231-234.

Young, B.; Lips, K. R.; Reaser, J. K.; IbáÑez, R.; Salas, A. W.; Credeño, J. R.; Coloma, L. A.; Ron, S.; la Marca, E.; Meyer, J. R.; Muñoz, A.; Bolaños, F.; Chaves, G. \& Romo, D. 2001. Population declines and priorities for Amphibian conservation in Latin America. Conservation Biology 15:1213-1223.

Zeisset, I. \& Beebee, T. J. C. 2003. Population genetics of a successful invader: the marsh frog Rana ridibunda in Britain. Molecular Ecology 12:639-646.

Recebido em abril de 2006. Aceito em novembro de 2008. ISSN 0073-4721

Artigo disponível em: www.scielo.br/isz 